\title{
REPORT ON STATUS OF EXECUTION OF SiC STEP DOCUMENT
}

\author{
Y. Katoh and K.A. Terrani \\ Oak Ridge National Laboratory
}

Date Published:

February 2015

Prepared by

OAK RIDGE NATIONAL LABORATORY

Oak Ridge, Tennessee 37831-6283

managed by

UT-BATTELLE, LLC

for the

U.S. DEPARTMENT OF ENERGY

under contract DE-AC05-00OR22725 



\section{CONTENTS}

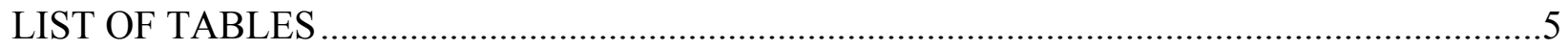

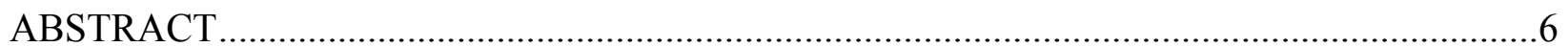

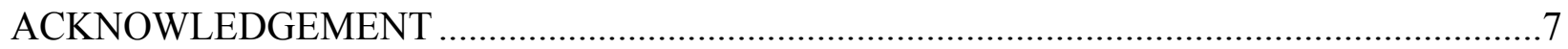

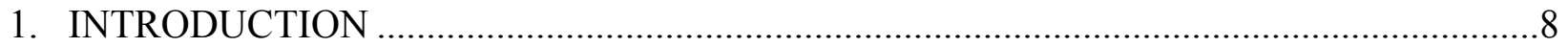

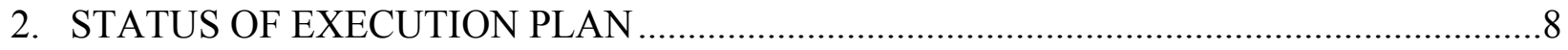

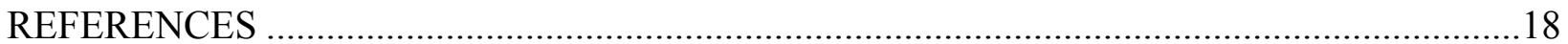





\section{LIST OF TABLES}

Table

Page

TABLE 1. EXECUTION STATUS OF ATF SIC SYSTEMATIC TECHNOLOGY EVALUATION PROGRAM IN THE TECHNICAL AREA OF DESIGN AND FAILURE.......9

TABLE 2. EXECUTION STATUS OF ATF SIC SYSTEMATIC TECHNOLOGY EVALUATION PROGRAM IN THE TECHNICAL AREA OF ENVIRONMENTAL EFFECTS. .14

TABLE 3. EXECUTION STATUS OF ATF SIC SYSTEMATIC TECHNOLOGY EVALUATION PROGRAM IN THE TECHNICAL AREA OF OFF-NORMAL BEHAVIOR CATEGORY. 


\begin{abstract}
Advanced fuel claddings made entirely or mainly of silicon carbide ( $\mathrm{SiC}$ ) ceramics and/or composites are considered very attractive elements of the accident-tolerant fuels for the light water reactors. In order to translate the promise of $\mathrm{SiC}$ composite materials into a reliable fuel cladding, a coordinated program of component level design and materials development must be carried out with many key feasibility issues addressed a-priori to inform the process. With the primary objective of developing a draft blueprint of a technical program that addresses the critical feasibility issues; assesses design and performance issues related with manufacturing, operating, and off-normal events; and advances the technological readiness levels in essential technology elements, a draft plan for the Systematic Technology Evaluation Program for $\mathrm{SiC} / \mathrm{SiC}$ Composite Accident-Tolerant LWR Fuel Cladding and Core Structures was developed in the FY-14 Advanced Fuels Campaign of the U.S. Department of Energy's Fuel Cycles Research and Development Program. This document summarizes the status of execution of the technical plan within the activities at the Oak Ridge National Laboratory.
\end{abstract}




\section{ACKNOWLEDGEMENT}

This work was sponsored by the U.S. Department of Energy, Office of Nuclear Energy, for the Advanced Fuels Campaign, Fuel Cycles Research and Development Program under contact DE-AC05-00OR22725 with Oak Ridge National Laboratories managed by UT-Battelle, LLC. 


\section{Introduction}

Silicon carbide $(\mathrm{SiC})$ composite-based fuel claddings are among the most attractive technology options for accident-tolerant fuels (ATF) for the light water reactors (LWR's) [1]. Here the $\mathrm{SiC}$ composites considered are limited to continuous and near-stoichiometric SiC fiberreinforced composites with stoichiometric and fully crystalline $\mathrm{SiC}$ matrices. The $\mathrm{SiC}$ compositebased fuel claddings that are currently considered for ATF for LWR's include fully ceramic composite cladding, layered cladding consisting of any combination of $\mathrm{SiC}$ composite and monolithic SiC layers, and a variety of ceramic-metal hybrid concepts that uses $\mathrm{SiC}$ composite as the primary structural element and a compliant metal to aid in fission product retention.

In order to translate the promise of $\mathrm{SiC}$ composite materials into a reliable fuel cladding, a coordinated program of component level design and materials development must be carried out with many key feasibility issues addressed a-priori to inform the process. With the primary objective of developing a draft blueprint of a technical program that addresses the critical feasibility issues; assesses design and performance issues related with manufacturing, operating, and off-normal events; and advances the technological readiness levels in essential technology elements, a draft plan for the Systematic Technology Evaluation Program (STEP) for SiC/SiC Composite Accident-Tolerant LWR Fuel Cladding and Core Structures was developed in the FY-14 Advanced Fuels Campaign of the U.S. Department of Energy's Fuel Cycles Research and Development Program [2]. A technical program in the SiC composite based ATF technology development area at the Oak Ridge National Laboratory (ORNL) was laid out starting in the fiscal year 2015 along the STEP plan. This document summarizes the status of execution of the technical plan within the activities at the ORNL.

\section{Status of Execution Plan}

The current status and near-term perspectives for the ATF SiC Technology Development STEP plan, technical areas of Design and Failure, Environmental Effects, and Off-Normal Behavior are summarized in Tables 1, 2, and 3, respectively. 
Table 1. Execution status of ATF SiC Systematic Technology Evaluation Program in the technical area of Design and Failure.

\begin{tabular}{|c|c|c|c|}
\hline No. & Task Name & Description & Status \\
\hline 1 & Design and Failure & & \\
\hline 1.1 & $\begin{array}{l}\text { Comprehensive } \\
\text { Analysis Tool } \\
\text { (MOOSE) }\end{array}$ & & \\
\hline 1.1 .1 & $\begin{array}{l}\text { Implementation of SiC } \\
\text { clad model in MOOSE }\end{array}$ & $\begin{array}{l}\text { 1) Implement the current 2D cylindrical (RZ) finite } \\
\text { element model in MOOSE, 2) Transition from 2D to 3D } \\
\text { analysis, and 3) Implement fuel pellet behavior and pellet- } \\
\text { clad interaction (PCI) }\end{array}$ & $\begin{array}{l}\text { Responsible principal researcher identified and } \\
\text { engaged for the FY15 work, which is currently in } \\
\text { progress. }\end{array}$ \\
\hline 1.1 .2 & Steady state analysis & $\begin{array}{l}\text { 1) Perform steady state RZ analysis as a function of } \\
\text { burnup for various design configurations and 2) Perform } \\
\text { steady state 3D analysis as a function of burnup for } \\
\text { various design configurations (axial and azimuthal flux } \\
\text { variation) }\end{array}$ & $\begin{array}{l}\text { Responsible principal researcher identified and } \\
\text { engaged for the FY15 work, which is currently in } \\
\text { progress. }\end{array}$ \\
\hline 1.1 .3 & Transient Analysis & $\begin{array}{l}\text { 1) Perform pin level power ramp analysis for SiC clad and } \\
\text { 2) Perform pin level RIA analysis for SiC clad }\end{array}$ & Not initiated. \\
\hline 1.2 & $\begin{array}{l}\text { Statistical Failure } \\
\text { Assessment }\end{array}$ & & \\
\hline 1.2 .1 & Definition and Tools & & \\
\hline 1.2.1.1 & $\begin{array}{l}\text { Define failure and } \\
\text { performance guideline }\end{array}$ & $\begin{array}{l}\text { The objectives of this task are to provide a definition of } \\
\text { fuel cladding failure, the failure modes of interest, and } \\
\text { guidelines for mechanical performance of fuel cladding. } \\
\text { The cladding failure will be defined by either/both of a } \\
\text { loss of gas tightness or/and structural failure. It is also } \\
\text { important to determine whether or not commonly used } \\
\text { failure criteria such as the proportional limit stress and } \\
\text { stress for the first major acoustic emission event may be } \\
\text { used as measures for loss of gas tightness. The failure } \\
\text { modes of primary interest will be determined based on } \\
\text { input from Task 1.1, though they are most likely } \\
\text { axial/hoop tension. The performance guidelines will } \\
\text { define the allowable failure rates (both gas tightness and } \\
\text { structural failure) for full-length articles. }\end{array}$ & $\begin{array}{l}\text { Preliminary definitions and statistical analysis of clad } \\
\text { failure are complete. A report on Preliminary Failure } \\
\text { Probability Estimation for Fully Ceramic Clad Option } \\
\text { was issued. This work is continuing with additional } \\
\text { input from Task 1.1. }\end{array}$ \\
\hline 1.2 .1 .2 & $\begin{array}{l}\text { Develop test } \\
\text { method/standard }\end{array}$ & $\begin{array}{l}\text { This task develops full-consensus test methods for the } \\
\text { failure modes defined above. ASTM Committee C } 28 \text { will be } \\
\text { chosen as the national standard authority for test methods }\end{array}$ & $\begin{array}{l}\text { Axial tensile test standard for ceramic composite tubes } \\
\text { has been published as an ASTM standard. Hoop tensile } \\
\text { test standard for ceramic composite tubes completed }\end{array}$ \\
\hline
\end{tabular}




\begin{tabular}{|c|c|c|c|}
\hline No. & Task Name & Description & Status \\
\hline & & $\begin{array}{l}\text { for ceramic matrix composites. The test method } \\
\text { development includes initial publication of an ASTM test } \\
\text { standard (through drafting/ballot/revision cycles), } \\
\text { determination of precision and bias (through a round- } \\
\text { robin program), and a revision to the published standard } \\
\text { to add a section on precision and bias. The round-robin } \\
\text { testing program will likely be combined with the statistical } \\
\text { properties data generation discussed in Task 1.2.2. The } \\
\text { work items initially considered will include a) axial } \\
\text { tension of tubes, b) hoop tension of tubes, c) acoustic } \\
\text { emission, and d) gas permeability. }\end{array}$ & $\begin{array}{l}\text { the initial drafting and is prepared for the spring ballo } \\
\text { at subcommittee level in ASTM C28.07 on Ceramic } \\
\text { Matrix Composites. Discussion was initiated toward } \\
\text { development of ASTM standards for acoustic emission } \\
\text { and gas permeability in ASTM C28 on Advanced } \\
\text { Ceramics. }\end{array}$ \\
\hline 1.2 .2 & $\begin{array}{l}\text { Statistical failure } \\
\text { characterization (for } \\
\text { each failure mode) }\end{array}$ & & \\
\hline 1.2 .2 .1 & $\begin{array}{l}\text { Test article and fixture } \\
\text { procurement }\end{array}$ & $\begin{array}{l}\text { This task will develop a specification for procurement of } \\
\text { test articles for failure modes of primary importance as } \\
\text { determined in Task 1.2.1, place procurement orders, and } \\
\text { visually inspect the test articles when they are received. } \\
\text { Test fixtures that will be distributed to the round-robin } \\
\text { studies will also be procured. }\end{array}$ & $\begin{array}{l}\text { Procurement specification development and } \\
\text { identification of a vender are complete. Contract was } \\
\text { recently placed. }\end{array}$ \\
\hline 1.2 .2 .2 & $\begin{array}{l}\text { Lead-tests for round- } \\
\text { robin studies }\end{array}$ & $\begin{array}{l}\text { Perform lead-tests based on draft ASTM test standards } \\
\text { and establish test procedures. }\end{array}$ & $\begin{array}{l}\text { A test specification and procedure document was } \\
\text { developed for the round robin testing for axial tensile } \\
\text { properties of ceramic composite tubes based on } \\
\text { testing of SiC composite tubes that had been } \\
\text { previously procured at ORNL. A similar lead-test will } \\
\text { be performed after the newly procured tubes are } \\
\text { received. }\end{array}$ \\
\hline 1.2 .2 .3 & $\begin{array}{l}\text { Coordination and } \\
\text { execution of round- } \\
\text { robin studies }\end{array}$ & $\begin{array}{l}\text { This task will identify the participating institutions and } \\
\text { responsible personnel for the round-robin studies, } \\
\text { develop the test procedure documents and report forms } \\
\text { based on the lead-test exercises, coordinate the round- } \\
\text { robin procedures, ensure that the tests are performed } \\
\text { according to the draft test standards and the procedure } \\
\text { documents, and collect results from the participants. }\end{array}$ & Potential participants have been identified. \\
\hline 1.2 .2 .4 & $\begin{array}{l}\text { Report on test data } \\
\text { acquisition and } \\
\text { analysis }\end{array}$ & $\begin{array}{l}\text { This task will reduce and analyze the results from the } \\
\text { round-robin studies, provide feed-back on the precision } \\
\text { and bias section to the pertinent ASTM standards, and } \\
\text { provide a recommendation of the probabilistic theory and }\end{array}$ & Will start after completion of the round-robin studies. \\
\hline
\end{tabular}




\begin{tabular}{|c|c|c|c|}
\hline No. & Task Name & Description & Status \\
\hline & & parameters to be used for failure probability analysis. & \\
\hline 1.2 .3 & $\begin{array}{l}\text { POF-based feasibility } \\
\text { assessment for ceramic } \\
\text { tube structures }\end{array}$ & & \\
\hline 1.2.3.1 & $\begin{array}{l}\text { Report on POF-based } \\
\text { feasibility assessment } \\
\text { for ceramic tube } \\
\text { structures }\end{array}$ & $\begin{array}{l}\text { This task will perform an assessment of technical } \\
\text { feasibility for fully-ceramic fuel cladding systems based on } \\
\text { the probabilistic failure properties of prototypical test } \\
\text { articles, size scaling of failure stresses, and the } \\
\text { requirement guidelines for fuel cladding performances. }\end{array}$ & $\begin{array}{l}\text { Will start after completion of the analysis of round- } \\
\text { robin results. }\end{array}$ \\
\hline 1.3 & $\begin{array}{l}\text { Fission Product } \\
\text { Transport }\end{array}$ & & \\
\hline 1.3 .1 & Issues analysis & $\begin{array}{l}\text { Analyze and report fission product transport. Linked with } \\
\text { gaseous FP transport in 1.2.1.2.4 and solid FP interactions } \\
\text { in 2.2.1. }\end{array}$ & $\begin{array}{l}\text { Responsible principal researcher identified and } \\
\text { engaged for the FY15 work, which is currently in } \\
\text { progress. }\end{array}$ \\
\hline$\overline{1.4}$ & $\begin{array}{l}\text { Design and } \\
\text { Manufacture }\end{array}$ & & \\
\hline 1.4 .1 & $\begin{array}{l}\text { Tubular CMC } \\
\text { structures }\end{array}$ & & \\
\hline 1.4 .1 .1 & Composite tube design & $\begin{array}{l}\text { This task identifies the reinforcement architectures and } \\
\text { composite fabrication methods for small diameter tubes } \\
\text { through an interaction with Task } 1.1 \text { so that the required } \\
\text { mechanical and thermal properties are satisfied with } \\
\text { affordable and scalable composite manufacture processes. } \\
\text { One or a few reference tube design(s) shall be defined in } \\
\text { this task to identify reference tube material(s) in } \\
\text { evaluation tasks and reference property values to Task } \\
\text { 1.1. }\end{array}$ & $\begin{array}{l}\text { Preliminary discussion was initiated in the R\&D } \\
\text { community of SiC ceramic composite ATF fuel cladding } \\
\text { involving industries and academia. }\end{array}$ \\
\hline 1.4 .1 .2 & $\begin{array}{l}\text { Manufacture issues } \\
\text { analysis }\end{array}$ & $\begin{array}{l}\text { This task will perform early analysis of manufacture issues } \\
\text { for thin-walled } \mathrm{SiC} / \mathrm{SiC} \text { tubes with an extreme length-to- } \\
\text { diameter ratio, based on survey of presently available } \\
\text { manufacture technologies for ceramic matrix composites } \\
\text { in various application fields. }\end{array}$ & $\begin{array}{l}\text { Preliminary discussion was initiated in the R\&D } \\
\text { community of SiC ceramic composite ATF fuel cladding } \\
\text { involving industries. }\end{array}$ \\
\hline 1.4.1.3 & Segmentation options & $\begin{array}{l}\text { Combining smaller length tubes into one full-length tube } \\
\text { structure is a potential option to build a SiC/SiC-based fuel } \\
\text { rod. This task will examine potential methods for } \\
\text { manufacturing full length fuel rods from segmented tubes } \\
\text { and status and development needs for the required }\end{array}$ & $\begin{array}{l}\text { Preliminary discussion was initiated in the R\&D } \\
\text { community of SiC ceramic composite ATF fuel cladding } \\
\text { involving industries. }\end{array}$ \\
\hline
\end{tabular}




\begin{tabular}{|c|c|c|c|}
\hline No. & Task Name & Description & Status \\
\hline & & $\begin{array}{l}\text { technology. Additionally, issues associated with an } \\
\text { alternative fuel assembly design option utilizing axially } \\
\text { segmented fuel rods will be examined. }\end{array}$ & \\
\hline 1.4.1.4 & $\begin{array}{l}\text { Preliminary } \\
\text { assessment for NDE } \\
\text { and QA requirements }\end{array}$ & $\begin{array}{l}\text { This task will identify requirements and needs for non- } \\
\text { destructive examination for } \mathrm{SiC} / \mathrm{SiC} \text {-based fuel clad tubes } \\
\text { and fuel rods for the purpose of quality assurance. }\end{array}$ & $\begin{array}{l}\text { Preliminary discussion was initiated in the R\&D } \\
\text { community of SiC ceramic composite ATF fuel cladding } \\
\text { involving industries and academia. }\end{array}$ \\
\hline 1.4 .2 & End plugs & & \\
\hline 1.4.2.1 & $\begin{array}{l}\text { Failure and } \\
\text { performance } \\
\text { guidelines }\end{array}$ & $\begin{array}{l}\text { This task will define failure for end-plugs and develop } \\
\text { preliminary guidelines for performance of end-plugs. The } \\
\text { failure modes will be defined in a consistent manner with } \\
\text { those for clad tubes. The performance guidelines will be } \\
\text { defined in terms of properties including mechanical, } \\
\text { thermophysical, irradiation, and oxidation. }\end{array}$ & $\begin{array}{l}\text { Preliminary discussion was initiated in the R\&D } \\
\text { community of SiC ceramic composite ATF fuel cladding } \\
\text { involving industries involved in FOA projects on end- } \\
\text { plug technology development. }\end{array}$ \\
\hline 1.4.2.2 & Joining development & $\begin{array}{l}\text { This task develops technology to join SiC/SiC to the end } \\
\text { plug material, most likely high purity monolithic SiC. } \\
\text { Future program should be built upon recent or ongoing } \\
\text { works supported by the LWR Sustainability Program. } \\
\text { Basic joining methods will be developed in geometries of } \\
\text { flat face joint and evaluated in simple modes. Development } \\
\text { of successful joining methods will be expanded to the end- } \\
\text { plug geometries. This task assumes the use of simple end- } \\
\text { plug geometries such as butted lap and scarf. Development } \\
\text { of more complex end-plug technologies such as those } \\
\text { involving mechanical locking or fastening mechanisms } \\
\text { may be considered, though. }\end{array}$ & $\begin{array}{l}\text { The flat joint torsion samples were prepared using } \\
\text { candidate joining methods for irradiation study. } \\
\text { Preliminary investigation into development and } \\
\text { evaluation of ceramic joints in end-plug relevant } \\
\text { geometries was initiated. }\end{array}$ \\
\hline 1.4.2.3 & Test methods & $\begin{array}{l}\text { Methods for testing end plug functions and performances } \\
\text { will be developed. As with Task 1.2, development of ASTM } \\
\text { test standards is assumed for all test methods to be } \\
\text { developed for the purpose of adequate quality assurance. } \\
\text { Effects of neutron irradiation and chemical environment } \\
\text { will not be included in this task but will be studied in Task } \\
\text { 2. Test methods to be developed will include those for 1) } \\
\text { shear strength of flat joints, 2) strength of end-plug joints, } \\
\text { and 3) gas tightness of end-plug joints. }\end{array}$ & $\begin{array}{l}\text { Torsional shear strength test standard for flat ceramic } \\
\text { joints completed the initial drafting and is prepared for } \\
\text { the spring ballot at subcommittee level in ASTM C } 28 \\
\text { on Advanced Ceramics. }\end{array}$ \\
\hline 1.4 .3 & Hybrid concepts & & \\
\hline 1.4.3.1 & $\begin{array}{l}\text { Initial assessment of } \\
\text { material systems }\end{array}$ & $\begin{array}{l}\text { This task identifies candidate coating materials or material } \\
\text { systems that provide adequate hydrothermal corrosion } \\
\text { resistance in normal LWR operating environments. The }\end{array}$ & $\begin{array}{l}\text { Candidate coating materials adequate for providing } \\
\text { hydrothermal corrosion resistance in normal LWR } \\
\text { operating environments were identified. }\end{array}$ \\
\hline
\end{tabular}




\begin{tabular}{|c|c|c|c|}
\hline No. & Task Name & Description & Status \\
\hline & & $\begin{array}{l}\text { coating material also needs to survive transient swelling of } \\
\text { SiC and retain sufficient gas tightness when penetrating } \\
\text { cracks develop through a SiC/SiC clad structure. Optimum } \\
\text { thickness of the coatings will also be determined. }\end{array}$ & \\
\hline 1.4 .3 .2 & $\begin{array}{l}\text { Processing } \\
\text { technologies }\end{array}$ & $\begin{array}{l}\text { Promising coating methods for candidate coating } \\
\text { materials or material systems selected in Task 1.4.3.1 will } \\
\text { be identified based on literature survey and } \\
\text { thermodynamic and reaction kinetics considerations. }\end{array}$ & $\begin{array}{l}\text { A method for metallic seed coating onto SiC surface } \\
\text { was identified. }\end{array}$ \\
\hline 1.4 .3 .3 & $\begin{array}{l}\text { Experimental } \\
\text { assessment }\end{array}$ & $\begin{array}{l}\text { Experimental assessment of coating processing } \\
\text { technologies identified in Task } 1.4 .3 .2 \text { will be performed. } \\
\text { Trial-fabricated coated samples will be examined for } \\
\text { baseline evaluation including physical integrity, } \\
\text { homogeneity, microstructures, and bonding strength. Note } \\
\text { that effects of neutron irradiation and chemical } \\
\text { environment will not be included in this task but will be } \\
\text { studied in Task } 2 \text {. }\end{array}$ & $\begin{array}{l}\text { A method for metallic seed coating onto SiC surface } \\
\text { identified in Task 1.4.3.2 was successfully } \\
\text { demonstrated. Effect of process condition on quality of } \\
\text { coating is being investigated. }\end{array}$ \\
\hline 1.4 .3 .4 & $\begin{array}{l}\text { Assessment of impact } \\
\text { on tube and joint } \\
\text { developments and } \\
\text { performance } \\
\text { requirements }\end{array}$ & $\begin{array}{l}\text { Influences of application of an enveloping coating of } \\
\mathrm{SiC} / \mathrm{SiC} \text {-based fuel rods with a ductile sealing layer on the } \\
\text { performance requirements for structural tubes and joints } \\
\text { will be addressed. }\end{array}$ & Preliminary investigation was initiated. \\
\hline
\end{tabular}


Table 2. Execution status of ATF SiC Systematic Technology Evaluation Program in the technical area of Environmental Effects.

\begin{tabular}{|c|c|c|c|}
\hline No. & Task Name & Description & Status \\
\hline 2 & Environmental Effects & & \\
\hline 2.1 & $\begin{array}{l}\text { Hydrothermal } \\
\text { corrosion }\end{array}$ & & \\
\hline 2.1 .1 & $\begin{array}{l}\text { Develop basic } \\
\text { thermodynamic basis } \\
\text { for the process }\end{array}$ & $\begin{array}{l}\text { 1) Develop and implement the database for all solid, } \\
\text { aqueous, and gaseous reactants and products, 2) Quantify } \\
\text { the thermodynamic driving force for } \mathrm{SiC} \text { - and } \mathrm{SiO}_{2}-\mathrm{H}_{2} \mathrm{O} \\
\text { reactions as a function of environmental conditions, 3) } \\
\text { Perform radiolysis simulations and input calculation } \\
\text { results to quantify the thermodynamic driving forces for } \\
\text { corrosion process under normal operating conditions, and } \\
\text { 4) Perform MD and input calculation results to modify the } \\
\text { thermodynamic driving forces for GB and other defects }\end{array}$ & $\begin{array}{l}\text { Basic thermodynamics and reaction kinetics data have } \\
\text { been acquired and analyzed, and the quantitative } \\
\text { evaluation of hydrothermal corrosion for the } \mathrm{SiC}-\mathrm{H}_{2} \mathrm{O} \\
\text { system was performed. }\end{array}$ \\
\hline 2.1 .2 & Autoclave testing & $\begin{array}{l}\text { 1) Test a matrix of SiC samples with varying impurity } \\
\text { levels and defect volumes for } 12 \text { months and collect data } \\
\text { every } 30 \text { days, 2) Characterize sample surface after } \\
\text { autoclave exposure, } 3 \text { ) Perform mechanical testing on } \\
\text { exposed specimens to quantify strength degradation (if } \\
\text { any), and 4) Perform autoclave testing and examination of } \\
\text { neutron irradiated and ion irradiated SiC samples. }\end{array}$ & $\begin{array}{l}\text { Work in progress with the first few mass evolution data } \\
\text { points successfully obtained for unirradiated test } \\
\text { specimens. }\end{array}$ \\
\hline 2.1 .3 & In-pile corrosion test & $\begin{array}{l}\text { 1) Test most resistant coupons in PWR/BWR in-pile loops } \\
\text { (Note: Need info from autoclave tests) and 2) PIE of in- } \\
\text { pile corrosion specimens. }\end{array}$ & $\begin{array}{l}\text { Preliminary discussion has been initiated with external } \\
\text { collaborators. A proposal to leverage ATR NSUF } \\
\text { resources has been put in place. }\end{array}$ \\
\hline 2.2 & FCCI and FCMI & & \\
\hline 2.2 .1 & FCCI & $\begin{array}{l}\text { 1) Diffusion bond preparation, aging, and examination } \\
\text { and 2) Thermodynamic analysis of equilibria (with high- } \\
\text { burnup chemical effects) }\end{array}$ & $\begin{array}{l}\text { SiC-Cr diffusion bonding was carried out from } 900- \\
1300^{\circ} \mathrm{C} \text {. Microscopic characterization of the bonds was } \\
\text { carried out. Isoplethal phase diagram of SiC-Cr was } \\
\text { produced using computation thermodynamic tools. }\end{array}$ \\
\hline 2.2 .2 & $\overline{\text { FCMI }}$ & $\begin{array}{l}\text { 1) Plug expansion tests at applicable stress for } \\
\text { unirradiated materials (Note: Need input from fuel } \\
\text { performance analysis and Tube), 2) Plug expansion tests } \\
\text { on irradiated cladding (if unavailable, mechanical tests on } \\
\text { irradiated specimen), and 3) Coupling FCMI results with } \\
\text { fuel performance analysis tool to predict failure } \\
\text { threshold. }\end{array}$ & Planning underway. \\
\hline 2.3 & Irradiation Effects & & \\
\hline
\end{tabular}




\begin{tabular}{|c|c|c|c|}
\hline No. & Task Name & Description & Status \\
\hline 2.3 .1 & $\begin{array}{l}\text { Swelling and irradiated } \\
\text { properties }\end{array}$ & & \\
\hline 2.3 .1 .1 & $\begin{array}{l}\text { Low temperature } \\
\text { swelling }\end{array}$ & $\begin{array}{l}\text { Existing data for swelling of SiC and SiC/SiC composites in } \\
\text { LWR-relevant irradiation conditions involve uncertainties } \\
\text { with regard to accuracy of swelling measurement and } \\
\text { irradiation temperature determination. This task will 1) } \\
\text { Perform experimental determination of swelling of high } \\
\text { purity CVD SiC and nuclear-grade SiC/SiC composites as a } \\
\text { function of neutron fluence at LWR-relevant low } \\
\text { temperatures. Put emphasis on accurate quantitative } \\
\text { measurement of dimensional changes and irradiation } \\
\text { temperature as compared to previously conducted } \\
\text { experiments, and 2) Establish high accuracy fluence- } \\
\text { dependence swelling development for high purity CVD SiC } \\
\text { through an instrumented in-situ reactor experiment. }\end{array}$ & $\begin{array}{l}\text { Accurate determination of swelling of high purity CVD } \\
\text { SiC and a nuclear grade SiC composite is complete for } \\
\text { specimens irradiated up to } 0.3 \text { dpa in HFIR in a } \\
\text { collaboration project with Electric Power Research } \\
\text { Institute. The planned } 1 \text { dpa irradiation experiment } \\
\text { failed due to unexpected malfunction of the hydraulic } \\
\text { rabbit facility of HFIR. Irradiation temperature } \\
\text { determination is underway for individual specimens. }\end{array}$ \\
\hline 2.3 .1 .2 & Irradiated properties & $\begin{array}{l}\text { Recent experimental study shows significant and } \\
\text { progressive degradation of Hi-Nicalon Type S, CVI-SiC } \\
\text { matrix composites' mechanical properties at high fluence } \\
\text { levels at an LWR-relevant low temperature. This task will } \\
\text { clarify fluence-dependent evolutions of baseline } \\
\text { mechanical and thermal properties at an LWR-relevant } \\
\text { temperature for Hi-Nicalon Type S and alternative SiC } \\
\text { fiber (Tyranno-SA3 and possibly SCS-Ultra SiC fibers) } \\
\text { composites. Irradiation effects data are needed for a dose } \\
\text { range } 8 \text { to at least } 30 \text { dpa at } \sim 280^{\circ} \mathrm{C} \text {. }\end{array}$ & $\begin{array}{l}\text { A new set of rabbit vehicles started irradiation in HFIR } \\
\text { after completion of capsule design, construction, and } \\
\text { safety approval. The materials irradiated include CVI } \\
\text { SiC-matrix composites with Hi-Nicalon Type S, } \\
\text { Tyranno-SA3, and SCS-Ultra SiC fibers. The first two } \\
\text { capsules are anticipated to complete irradiation in } \\
\text { August of } 2015 .\end{array}$ \\
\hline 2.3 .2 & Irradiation creep & & \\
\hline 2.3 .2 .1 & In-pile creep of $\mathrm{SiC}$ & $\begin{array}{l}\text { Small but finite irradiation creep has been reported for } \\
\text { relevant SiC materials. This task will determine the } \\
\text { irradiation creep behavior of high purity CVD SiC at an } \\
\text { LWR-relevant temperature to a high accuracy through an } \\
\text { instrumented reactor experiment. }\end{array}$ & $\begin{array}{l}\text { Experiment in Halden reactor facility has been } \\
\text { designed, implemented, and the irradiation experiment } \\
\text { is to be initiated in March } 2015 \text {. }\end{array}$ \\
\hline 2.3 .2 .2 & In-pile creep of joints & $\begin{array}{l}\text { In } \mathrm{SiC} / \mathrm{SiC} \text {-based fuel clads, the end-plug joints will likely } \\
\text { be the weakest link for possible irradiation creep-induced } \\
\text { failure. This task will experimentally evaluate irradiation } \\
\text { creep behavior of candidate joints or joining materials in } \\
\text { a shear deformation mode after down-selection of most } \\
\text { promising joints in Tasks } 1.4 .2 \text { and } 2.3 .3 \text {. Moreover, end- } \\
\text { plug joints considered for the hybrid clad concepts will be }\end{array}$ & Not yet started. \\
\hline
\end{tabular}




\begin{tabular}{|c|c|c|c|}
\hline No. & Task Name & Description & Status \\
\hline & & $\begin{array}{l}\text { evaluated. Because shear irradiation creep of joint articles } \\
\text { with a thin-layered bonding layer has not previously } \\
\text { evaluated, experimental method first needs to be } \\
\text { developed. }\end{array}$ & \\
\hline 2.3 .3 & $\begin{array}{l}\text { Irradiation effects on } \\
\text { joints }\end{array}$ & & \\
\hline 2.3.3.1 & $\begin{array}{l}\text { Irradiation effects in } \\
\text { flat joint test articles }\end{array}$ & $\begin{array}{l}\text { This task will evaluate the effects of neutron irradiation } \\
\text { on shear strength and microstructures of joints down- } \\
\text { selected in Task } 1.4 \text { using torsional shear test specimens } \\
\text { with flat face joint layers. Establishment of an applicable } \\
\text { test method in Task 1.4.2.3 is a pre-requisite. Structural } \\
\text { and phase stability of the bonding materials and } \\
\text { interfaces and consequences of likely differential swelling } \\
\text { behavior between SiC and bonding material are of } \\
\text { primary interest. }\end{array}$ & $\begin{array}{l}\text { Irradiation program in HFIR is in progress with the flat } \\
\text { joint torsion samples prepared using candidate joining } \\
\text { methods, irradiation vehicles designed, constructed and } \\
\text { safety-approved, and all vehicles completed } \sim 8 \mathrm{dpa} \\
\text { irradiation in reactor in February } 2015 \text {. Post- } \\
\text { irradiation examination (PIE) will be initiated after } \\
\text { necessary cooling, capsule transfer and disassembly, } \\
\text { and specimen shipment to the PIE facility. }\end{array}$ \\
\hline 2.3.3.2 & $\begin{array}{l}\text { Irradiation effects in } \\
\text { end-plug geometry }\end{array}$ & $\begin{array}{l}\text { In three-dimensional joint structures, the effect of } \\
\text { differential dimensional evolutions between SiC and } \\
\text { bonding material will be more severe than in flat face } \\
\text { joint geometries. Moreover, the end-plug geometry is } \\
\text { more appropriate both for measurement of gas } \\
\text { permeability and for other properties (primarily } \\
\text { strength) evaluation using in a relevant geometry. This } \\
\text { task will evaluate gas permeability and mechanical } \\
\text { properties of prototypical end-plug section test articles } \\
\text { following neutron irradiation in LWR-relevant conditions. } \\
\text { Test articles shall be made using the reference and/or } \\
\text { candidate SiC/SiC tubes, as defined in Task 1.4, and } \\
\text { candidate joining technologies that completed the } \\
\text { baseline irradiation study in Task 2.3.3.1, and be tested by } \\
\text { test methods developed in Task 1.4.2.3. }\end{array}$ & $\begin{array}{l}\text { This effort will be initiated after successful } \\
\text { development of test articles and test method. }\end{array}$ \\
\hline 2.3 .4 & $\begin{array}{l}\text { Irradiation effects in } \\
\text { coated systems }\end{array}$ & $\begin{array}{l}\text { As the first step of evaluating irradiation effects on hybrid } \\
\text { clad tubes, the effects of neutron irradiation on integrity } \\
\text { of the sealing function and the substrate-coating bonding } \\
\text { strength in an LWR-relevant irradiation condition need to } \\
\text { be determined. More focused objectives and technical } \\
\text { approach of this task will be defined after the candidate } \\
\text { hybrid concepts and the specific technical issues are } \\
\text { defined in Task 1.4.3. }\end{array}$ & $\begin{array}{l}\text { This effort will be initiated after successful } \\
\text { development of candidate coated materials. }\end{array}$ \\
\hline
\end{tabular}


Table 3. Execution status of ATF SiC Systematic Technology Evaluation Program in the technical area of Off-normal Behavior category.

\begin{tabular}{|c|c|c|c|}
\hline No. & Task Name & Description & Status \\
\hline 3 & $\begin{array}{l}\text { Off-normal } \\
\text { Environmental Effects }\end{array}$ & & \\
\hline 3.1 & Steam oxidation & $\begin{array}{l}\text { 1) Steam exposure of monolithic and model composite } \\
\text { materials to high temperatures, 2) Steam exposure of SiC } \\
\text { Joints to high temperatures, and 3) Steam exposure of } \\
\text { candidate fully ceramic composites and hybrid SiC } \\
\text { concepts to high temperatures. }\end{array}$ & $\begin{array}{l}\text { Work on steam testing of } \mathrm{SiC} \text { and } \mathrm{SiC} \text { joints in alumina } \\
\text { free tube furnaces is in progress. Planning is underway } \\
\text { for the hybrid concepts. }\end{array}$ \\
\hline 3.2 & Thermal shock & $\begin{array}{l}\text { 1) Thermal hydraulic analysis of quench conditions, 2) } \\
\text { Quench test setup and execution for various cladding } \\
\text { configurations (Note: Need input on tube design), and 3) } \\
\text { Quench stress analysis for pressurized and de-pressurized } \\
\text { cladding. }\end{array}$ & Planning underway. \\
\hline 3.3 & Accident analysis & $\begin{array}{l}\text { Using TMI-2 or Fukushima-3 as the baseline accident case, } \\
\text { evaluate the performance of } 1 \text { ) Fully ceramic } \mathrm{SiC} / \mathrm{SiC} \\
\text { cladding (all other materials remain standard), 2) } \mathrm{SiC} / \mathrm{SiC} \\
\text { - Zircaloy hybrid cladding, and } 3 \text { ) SiC/SiC structures with } \\
\text { standard Zircaloy cladding (assess the relative impact of } \\
\text { SiC as a cladding vs. structural material with regard to } \\
\text { total hydrogen production, maximum cladding } \\
\text { temperature, oxidation heating, time to core melt, etc.). As } \\
\text { the result, working MELCOR } 1.8 .6 \text { code structure that } \\
\text { allows fully decoupled structural and cladding } \\
\text { components in the PWR case will be developed. }\end{array}$ & Planning underway. \\
\hline
\end{tabular}




\section{REFERENCES}

[1] S. J. Zinkle, K. A. Terrani, J. C. Gehin, L. J. Ott, and L. L. Snead, "Accident tolerant fuels for LWRs: A perspective," Journal of Nuclear Materials, vol. 448, pp. 374-379, 2014.

[2] Y. Katoh, K. A. Terrani, and L. L. Snead, "ORNL/TM-2014/210, Revison 1, Systematic Technology Evaluation Program for SiC/SiC Compositebased Accident-Tolerant LWR Fuel Cladding and Core Structures," June 2014. 